\title{
Productivity enhancement in Finger millet through Frontline demonstration in Dharmapuri district of Tamil Nadu, India: A case study
}

\section{Sangeetha*}

ICAR-Krishi Vigyan Kendra, Tamil Nadu Agricultural University, Dharmapuri District (Tamil Nadu), India

\section{N.Tamil Selvan}

Regional Research Station, Tamil Nadu Agricultural University, Paiyur, Krishnagiri District, (Tamil Nadu), India

\section{P.S.Shanmugam}

ICAR-Krishi Vigyan Kendra, Tamil Nadu Agricultural University, Dharmapuri District (Tamil Nadu), India

\section{M.A.Vennila}

ICAR-Krishi Vigyan Kendra, Tamil Nadu Agricultural University, Dharmapuri District (Tamil Nadu), India

${ }^{*}$ Corresponding author. E-mail: sangeetha_cm@yahoo.com

\begin{abstract}
Frontline demonstration was taken up in farmers' holdings of Dharmapuri district, Tamil Nadu, India during kharif 2015 to create awareness among the farmers and demonstrate the improved production technologies in finger millet. The integrated crop management practices including cultivation of drought tolerant and short duration finger millet variety ML 365, integrated nutrient management, integrated pest and disease management practices were demonstrated and compared with the existing farmers practice followed in Finger millet cultivation. Results showed that demonstration of finger millet variety ML 365 with integrated crop management practices recorded higher grain yield of $2100 \mathrm{~kg} /$ ha and farmers practice recorded lower yield of $1730 \mathrm{~kg} / \mathrm{ha}$. Adoption of integrated crop management practices increased the grain yield of finger millet to the tune of 21.7 per cent compared to farmers practice. Farmers earned higher net income of Rs.14244/ha through the demonstration and Rs.10018/ha with farmers practice. Besides, farmers realized higher benefit cost ratio (1.58) through the demonstration compared to farmers practice (1.46). Thus, the frontline demonstration of improved variety with crop management practices increased the grain yield and net income of the farmers growing finger millet under rainfed condition. In the present study, potential of the improved variety and technologies were demonstrated systematically and scientifically in the farmers field along with farmers practice for further adoption by farming community in large scale.
\end{abstract}

Keywords : Benefit cost ratio, Demonstration, Finger millet, Grain yield, Net income

\section{INTRODUCTION}

Finger millet (Eleusine coracana L. Gaertn) is one of the important millets grown extensively in Dharmapuri District. It is a hardy crop, has good adaption to wide range of environment especially heat, drought, marginal and degraded soils (Okalebo et al., 1991). It is mainly grown for its grains and it is highly nutritious. Its grains contain carbohydrate $(65-75 \%)$, protein $(5-8 \%)$, dietary fibre $(15-20 \%)$, minerals $(2.5-3.5 \%)$ and vitamins (Chethan and Malleshi, 2007). It is superior to rice and wheat, in respect of crude fibre, amino acids and minerals like calcium (344 $\mathrm{mg} / 100 \mathrm{~g})$ and potassium (408 $\mathrm{mg} / 100 \mathrm{~g}$ ). It also contains anti nutrients such as phytates, polyphenols, tannins and trypsin inhibito-

\section{Article Info}

DOI:10.31018/jans.v11i1.1946 Received: November 12, 2018 Revised: February 12, 2019 Accepted: February 15, 2019

\section{How to Cite}

Sangeetha, M. et al. (2019). Productivity enhancement in Finger millet through Frontline demonstration in Dharmapuri district of Tamil Nadu, India: A case study. Journal of Applied and Natural Science, 11(1): 130-133 
cultivated under rainfed condition during kharif season. Under rainfed condition, farmers facing the problem of moisture stress at various crop growth stages thereby experiencing low yield and crop loss to some extent. Besides moisture stress, lack of knowledge on the availability of drought tolerant varieties, non adoption of improved cultivation practices, prevalence of nutrient deficiency, pest and disease incidence also lowers the finger millet productivity. Hence, the productivity of finger millet might be increased by growing suitable variety along with improved crop management practices. Similar studies on crop yield increase by adoption of improved crop management practices were reported by Subhashree et al. (2017) in Finger millet; Sharma et al. (2016) and Singh (2017) in Wheat; Jat and Gupta (2015) in Pearl millet; Meena et al., (2014) in Maize.

Considering the above facts, a frontline demonstration was proposed and conducted in the farmers' holdings to demonstrate the improved package of practices for higher productivity in finger millet under rainfed condition.

\section{MATERIALS AND METHODS}

Frontline demonstration was conducted to demonstrate the potential of the drought tolerant, short duration variety with the improved package of practices in comparison with the existing farmers practice in the farmers' holdings of Dharmapuri district during kharif 2015 under rainfed condition. Demonstration was conducted in 20 locations spread over in Pennagaram, Palacode, Karimangalam, Nallampalli, Morappur and Pappireddipatty blocks of Dharmapuri District. The soils of the demonstration fields were collected and analysed for its initial soil nutrients status. The results showed that the soils were slightly alkaline in soil reaction, non saline, low in nitrogen, medium in phosphorus and potassium nutrient content. Each demonstration was conducted in an area of 0.4 ha and with an adjacent area of 0.4 ha selected for farmers practice. In the demonstration, the improved practices including cultivation of finger millet variety $M L 365$, integrated nutrient management, integrated pest and disease management practices were demonstrated along with the farmers practice. Finger millet variety ML 365 was released from University of Agricultural Sciences, Bengaluru during 2008. It has 100-105 days duration, high yielding variety, tolerant to drought and blast disease. In farmers practice, finger millet variety GPU 28 was grown with the existing farmers practices such as broadcasting of seeds, basal application of complex fertilizers, etc. The details on the technological interventions followed in the demonstration and farmers practice were given in Table 1. Before initiating the demonstration, the beneficiary farmers were trained in all the improved practices in finger millet cultivation and followed in the demonstrations. Demonstration field were periodically observed by the scientists of Krishi vigyan kendra, Dharmapuri and advisory recommendations given in Crop Production Guide 2012, Tamil Nadu Agricultural University were followed.

At the time of harvest, the data on plant population (number), plant height $(\mathrm{cm})$, number of tillers per plant (number), days taken for $50 \%$ flowering (number) and grain yield (kg/ha) of finger millet crop were recorded from both the demonstration and farmers practice. Based on the cost of inputs and market price of the produce, economic parameters such as net return (Rs/ha) and benefit cost ratio were worked out.

\section{RESULTS AND DISCUSSION}

Results of the study indicated that demonstration

Table 1. Technological interventions followed in finger millet cultivation under demonstration and farmers practice in Dharmapuri district during 2015.

\begin{tabular}{|c|c|c|c|}
\hline S.N. & $\begin{array}{l}\text { Technological } \\
\text { interventions }\end{array}$ & Existing Farmers practice & $\begin{array}{l}\text { Improved practices demonstrated through } \\
\text { frontline demonstration }\end{array}$ \\
\hline 1 & Farming situation & Rainfed & Rainfed \\
\hline 2 & Variety & Cultivation of GPU 28 & Cultivation of ML 365 \\
\hline 3 & Time of sowing & First week of August & First week of August \\
\hline 4 & Method of sowing & $\begin{array}{l}\text { Broadcasting of seeds and } \\
\text { thinning operation was not } \\
\text { followed }\end{array}$ & $\begin{array}{l}\text { Broadcasting of seeds and spacing of } 30 \times 10 \\
\mathrm{~cm} \text { was followed by thinning and gap filling } \\
\text { operation }\end{array}$ \\
\hline 5 & $\begin{array}{l}\text { Seed } \\
\text { practice }\end{array}$ & Not followed & $\begin{array}{l}\text { Seed treatment with Pseudomonas fluo- } \\
\text { rescens @ } 10 \mathrm{~g} / \mathrm{kg} \text { followed by biofertilizers } \\
\text { viz., Azospirillum and Phospho bacteria each } \\
\text { @ } 25 \mathrm{~g} / \mathrm{kg}\end{array}$ \\
\hline 6 & $\begin{array}{l}\text { Nutrient } \\
\text { ment }\end{array}$ & $\begin{array}{l}\text { Basal application of } 20: 20: 20 \\
\text { complex fertilizer @ } 125 \mathrm{~kg} / \mathrm{ha}\end{array}$ & $\begin{array}{l}\text { Basal application of FYM @ } 12.5 \mathrm{t} / \mathrm{ha} \text {; Rec- } \\
\text { ommended dose of NPK @ 40:20:20 kg/ha; } \\
\text { Soil application of TNAU millet micronutrient } \\
\text { mixture @ } 7.5 \mathrm{~kg} / \mathrm{ha}\end{array}$ \\
\hline 7 & Weed management & Not followed & $\begin{array}{l}\text { One hand weeding on 25-30 Days after sow- } \\
\text { ing }\end{array}$ \\
\hline 8 & IPDM practices & $\begin{array}{l}\text { No prophylactic or control } \\
\text { measures for managing pests } \\
\text { and diseases }\end{array}$ & $\begin{array}{l}\text { Need based usage of plant protection chemi- } \\
\text { cals and IDM practices for blast disease was } \\
\text { followed }\end{array}$ \\
\hline
\end{tabular}


Table 2. Growth parameters of finger millet varieties GPU 28 and ML 365 as influenced by farming practices .

\begin{tabular}{lllll}
\hline Treatments & $\begin{array}{l}\text { Plant population at } \\
\text { harvest (No./m } \mathbf{m}^{2}\end{array}$ & $\begin{array}{l}\text { Plant height } \\
(\mathbf{c m})\end{array}$ & $\begin{array}{l}\text { Number of tiller } \\
\text { per plant }\end{array}$ & $\begin{array}{l}\text { Days to 50\% } \\
\text { flowering }\end{array}$ \\
\hline $\begin{array}{l}\text { Farmers practice (GPU 28) } \\
\text { Demonstration of improved }\end{array}$ & 26.1 & 65.8 & 2.41 & 64 \\
practices (ML 365) & 35.3 & 76.4 & 4.56 & 70
\end{tabular}

Table 3. Yield and economics of finger millet varieties GPU 28 and ML 365 as influenced by farming practices.

\begin{tabular}{|c|c|c|c|c|c|}
\hline Treatments & $\begin{array}{l}\text { Grain yield } \\
\text { (kg/ha) }\end{array}$ & $\begin{array}{lr}\text { Percent } & \text { yield } \\
\text { increase } & \text { over } \\
\text { farmers practice }\end{array}$ & $\begin{array}{l}\text { Gross Cost } \\
\text { (Rs./ha) }\end{array}$ & $\begin{array}{l}\text { Net } \\
\text { income } \\
\text { (Rs/ha) }\end{array}$ & $\begin{array}{l}\text { Benefit } \\
\text { Cost Ratio }\end{array}$ \\
\hline Farmers practice (GPU 28) & 1730 & - & 21723 & 10018 & 1.46 \\
\hline $\begin{array}{l}\text { Demonstration of improved } \\
\text { practices (ML 365) }\end{array}$ & 2100 & 21.7 & 24405 & 14244 & 1.58 \\
\hline
\end{tabular}

of drought tolerant finger millet variety ML 365 with integrated crop management practices recorded the higher plant population $\left(35.3 / \mathrm{m}^{2}\right)$, plant height $(76.4 \mathrm{~cm})$ and higher number of tillers per plant (4.56). Lower plant population $\left(26.1 / \mathrm{m}^{2}\right)$, plant height $(65.8 \mathrm{~cm})$ and number of tillers per plant (2.41) were recorded in farmers practice during 2015 (Table 2). The demonstrated variety attained maturity one week earlier than the existing local variety.

Cultivation of drought tolerant finger millet variety ML 365 with integrated crop management practices recorded higher average grain yield of $2100 \mathrm{~kg} /$ ha (Table 3). Farmers practice recorded lower average grain yield of $1730 \mathrm{~kg} / \mathrm{ha}$. Adoption of improved practices increased the yield of finger millet to the tune of 21.7 per cent compared to the farmers practice under rainfed condition. The increased yield under demonstration might be due to the combined effect of high yielding, drought tolerant variety and adoption of improved crop management practices. The similar results of yield enhancement through front line demonstration of improved technologies has been reported by Kumar et al. (2010) in bajra; Solanki et al. (2014) in maize and Anand Naik et al., (2016) in sorghum. Besides, the incidence of blast disease was not reported in the demonstrated variety and it was 8 per cent in the farmers practice.

The data on economic indicators indicated that, the cost of production was higher in demonstration (Rs. 24,405/ha) and lower in farmers practice (Rs. 21,723/ha) (Table 3). Farmers earned the net income of about Rs.14,244/ha through the cultivation of ML 365 variety with integrated crop management practices and Rs.10,018/ha with farmers practice. On an average Rs. 4226/ha as additional income is attributed to the higher yield obtained in demonstration. Hence, farmers realized the higher benefit cost ratio (1.58) through the cultivation of ML 365 variety with integrated crop management practices compared to farmers practice (1.46). It might be due to the higher grain yield recorded in demonstration compared to farmers practice. Similar results of increase in net income and benefit cost ratio due to adoption of improved technolo- gies in the demonstrations were reported by Jat and Gupta (2015) in pearl millet; Dhaka et al., (2010) in maize and Anand Naik et al., (2016) in sorghum.

\section{Conclusion}

Results of the demonstration revealed that cultivation of finger millet variety ML 365 with integrated crop management practices increased the yield and income of the farmers under rainfed condition. In addition, the introduced variety has satisfied the farmers preferences such as high tiller production, early maturity and tolerance to grain shattering or dusting. Hence, the farmers were convinced with the performance of the variety with regard to its yield potential and tolerance to biotic and abiotic stresses under rainfed condition.

\section{REFERENCES}

1. Anand Naik, Raju, G., Teggelli, Zaheer Ahamed, B. and Devappagouda H. Patil. (2016). Yield gap analysis of sorghum through front line demonstrations in Kalaburagi region of northern Karnataka. Res. Environ. Life Sci., 9(5): 597-598.

2. Chethan, S. and Malleshi, N.G. (2007). Finger millet polyphenols: characterization and their nutraceutical potential. Am. J. Food Technol., 2 (7): 582-592. DOI: 10.3923/ajft.2007.582.592

3. Devi, P.B., Vijayabharathi, R., Sathyabama, S., Malleshi, N.G. and Priyadarisini, V.B. (2014). Health benefits of finger millet (Eleusine coracana L.) polyphenols and dietary fibre: a review. J. Food Sci. Technol., 51(6): 1021-1040. DOI: 10.1007/s13197-0110584-9

4. Dhaka, B.L., Meena, B.S. and Suwalka, R.L. (2010). Popularization of improved maize production technology through frontline demonstrations in south-eastern Rajasthan. Journal of Agricultural Science, 1(1): 3942. DOI: 10.1080/09766898.2010.11884652

5. Jat, B. L. and Gupta, J. K. (2015). Yield gap analysis of pearl millet through frontline demonstrations in Dausa district of Rajasthan. Karnataka. J. Agric. Sci., 28(1): 104-106.

6. Kumar, A., Kumar, R., Yadav, V.P.S. and Kumar, R.A. (2010). Impact assessment of frontline demonstrations of bajra in Haryana state. Indian Res. J. Ext. Edu., 10 (1): 105-108.

7. Meena, B. L., Meena, R. P., Meena, R. R., \& Singh, B. (2014). Popularization of improved maize (Zea mays L.) production technology through frontline 
demonstrations in semi arid zone IVA of Rajasthan. Journal of Applied and Natural Science, 6(2), 763769. https://doi.org/10.31018/jans.v6i2.533

8. Okalebo, J.R., Jutto, P.M. and Gathera, K.W. (1991). Effect of form and method of phosphate fertilizer application on maize, sorghum and millet growth in semi-arid environment of Kenya. II. Effect of bulrush and finger millet. East African Forestry Journal, 55: 239-248.

9. Sharma,V., Vijay Kumar, Sharma, S.C. and Sukhvinder Singh. (2016). Productivity enhancement and popularization of improved production technologies in wheat through frontline demonstrations. Journal of Applied and Natural Science, 8 (1): 423-428. DOI: 10.31018/jans.v8i1.810
10.Singh, S.B. (2017). Impact of frontline demonstrations on yield of wheat (Triticum aestivum) under rain fed condition in Uttarakhand. International Journal of Science, Environment and Technology, 6(1): 779 786.

11.Solanki, R.L., Rathore, R.S., Dhakar, S.D. and Kanojia, Y. (2014). Yield gap analysis of integrated nutrient management in maize through front line demonstration. International Journal of Plant Sciences, 9(2): 438-440.

12.Subhashree, K.S., Ravishankar, C.R., Raveendra, H.R., Madhusudhan, K. (2017). Economic impact of front line demonstrations on finger millet yields. Agriculture Update, 12(1): 169-171. DOI : 10.15740/HAS/ AU/12.1/169-171 